\section{En viktig bok}

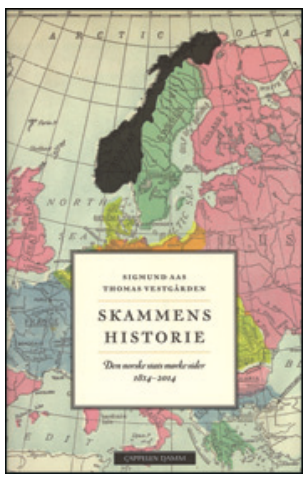

Sigmund Aas, Thomas Vestgården

\section{Skammens historie}

Den norske stats mørke sider 1814-2014.

319 s. Oslo: Cappelen Damm, 2014

Pris NOK 349

ISBN 978-82-02-38839-3
I år er den norske grunnloven 200 år, og det er grunn til å lovprise eidsvollsmennene. Men er det ikke riktig og viktig at også de mørke sidene av norsk historie blir belyst?

Da den frittalende bonden fra Aust-Agder, Theis Jacob Thorkildsen Lundegaard, i debatten på Eidsvoll ropte: «Stå opp, den som ingen jøder vil ha i riket», reiste flertallet av representantene seg umiddelbart, og dermed ble Grunnloven $\S 2$, jødeparagrafen, vedtatt. Den sa blant annet at «jesuitter og munkeordener må ikke tåles. Jøder er fremdeles utelukkede fra adgang til riket». Først i 1851 fikk jøder adgang til Norge, men motstanden mot jødene besto. Således skrev Aftenposten i 1924: «Jødene kommer inn som sildestim. De sætter seg fast over hele byen, Det er snart ikke en fruktbutikk, et utsalg av brukte klær (...) der staar en smilende jøde bak disken. Men bare vent snart vi finder dem indenfor en avis, en bank, universitetet og Nasjonalgalleriet.» Høsten 1942 ble 770 jøder arrestert her i landet og sendt til tyske dødsleirer med god hjelp av norsk politi.

På 1800-tallet og langt ut på 1900-tallet var den norske stats holdning til romanifolket at det var et degenerert og kriminelt folk, som ville forringe den norske befolknings kvalitet, om de ble assimilert. Steriliseringsloven, som ble vedtatt i 1934, ga adgang til å tvangssterilisere åndssvake, sinnssyke og sedelighetsforbrytere. Sannsynligvis ble om lag 500 romanikvinner sterilisert.

Livet i norske fengsler var helt opp til nyere tid preget av vold og pinsler. De fleste fangene på Akershus satt der på livstid, med halsjern og fotjern som kunne veie opptil $30 \mathrm{~kg}$. Pisking var vanlig. Utover på 1800-tallet ble det bygd flere anstalter for «slemme gutter». En av de mest kjente var Bastøya i Oslofjorden, der gutter helt ned til 8-årsalderen ble avstraffet, ofte slått og pisket. I mørke, stinkende kalde bur i kjelleren kunne gutter bli sittende alene i opptil tre uker, forfrosne, med lite mat.

Justismordet på Fritz Moen er uten sidestykke i norsk rettshistorie. Moen var døv med manglende språkferdigheter og «tyskerbarn». I 1978 ble han dømt til tjue års fengsel og ti års sikring for voldtekt og mord. I alt sonet han 18 forferdelige år på Ila før han ble frikjent, takket være privatetterforsker Tore Sandberg.

Landssvikoppgjøret ble gjennomført etter lover med tilbakevirkende kraft, i strid med Grunnloven, og 25 nazister ble henrettet på tross av at dødsstraff var blitt avskaffet her i landet i 1902. Av de bortimot 15000 kvinner som var sammen med tyske soldater under krigen, ble mange med barn sendt til et utbombet Tyskland. Det er også rapporter om tortur av landssvikfanger, utført av norske fangevoktere etter krigen.

Krigsseilere som etter å ha risikert livet gjennom flere angstfylte krigsår, ble ikke bare snytt for sin rettmessige lønn, men ble også behandlet på en uverdig måte av samfunnet.
Ved stortingsvalget i 1945 hadde kommunistene fătt 11 representanter på Stortinget, og AP forhandlet den gang om sammenslåing av de to partiene. Men i Kråkerøy-talen i 1948 uttalte Gerhardsen at «den viktigste oppgave i kampen for Norges selvstendighet, for demokratiet og rettssikkerheten er å redusere kommunistpartiet og kommunistenes innflytelse mest mulig». I august 1950 la justisminister Gundersen frem for Stortinget et lovforslag som ga staten anledning til, under krig og krise eller «når krig truer», å innføre internering uten lov og dom, pressesensur og summarisk rettergang med eventuell dødsstraff. Forslagene utløste imidlertid sterk protest, slik at loven ble forkastet av Stortinget. I stedet fikk man senere en fullmaktslov som egentlig ga regjeringen friere tømmer til å sette i verk både forræderidomstoler, pressesensur, internering eller dødsstraff hvis den fant det nødvendig.

Både POT og E-tjenesten avlyttet alt de kunne makte av møter i kommunistiske organisasjoner landet rundt i 1950-årene. Faktisk avlyttet toppledelsen i LO i samarbeid med Aps ledelse og de hemmelige tjenester i flere år gjennom skjulte mikrofoner i Folkets Hus på Youngstorget partifeller, fagforeningsfolk og politiske motstandere helt systematisk. Senere ble lederne i de venstreorienterte miljøene rundt SUF, SF og AKP(m-l) også med overvåking av deres privatliv.

Amerikanske fly slapp flere bomber over Korea enn det som ble sluppet over Europa under hele den annen verdenskrig. Av dette var det 30000 napalmbomber. Det er anslått at to millioner mennesker ble drept, kanskje én million var sivile. Norsk Hydro bidro til å lage slike våpen i 1950-årene ved å levere store mengder magnesium til USA. Ved salg av tungtvann medvirket Norge, ved Jens Christian Hauge, også til at Israel fikk produsert atomvåpen. Staten har dessuten gjennom Oljefondet investert i selskaper som driver med våpenhandel og produksjon av atomvåpen. Ikke minst ble det investert i selskaper som produserte landminer og klasevåpen, som var lite treffsikre mot militære mål, men som tar sivile liv i stedet.

For yngre lesere vil mye av stoffet i denne boken være nytt. Vi eldre vil bli minnet om ting vi har glemt, eller bli «beriket» med nye sjokkerende detaljer. Boken gir en interessant og balansert fremstilling med visse mindre unntak. Lobotomien var et trist kapittel i norsk psykiatri, men er for ensidig fremstilt. Man stusser også over at Lund-kommisjonen knapt er nevnt, og at Bjugn-saken ikke er omtalt.

\section{Einar Kringlen}

Professor emeritus, Psykiatrisk institutt, Vinderen, Universitet i Oslo 